\title{
Spatial variability and geostatistical analysis of selected soil
}

\author{
M. Z. Khan, M. A. Islam, M. Sadiqul Amin* and M. M. R. Bhuiyan
}

Soil, Water and Environment Discipline, Khulna University, Khulna-9208, Bangladesh

Received: 12 January 2018

Revised: 17 April 2018

Accepted: 23 May 2018

DOI: https://doi.org/10.3329/bjsir.v54i1.40731

\begin{abstract}
A study was conducted to explore the spatial variability of major soil nutrients of Agricultural fields in South-western region of Bangladesh. From the study area, 40 surface soil samples were collected by a random sampling strategy using GPS. Then soil physico-chemical properties i.e., $\mathrm{pH}$, electrical conductivity $(\mathrm{EC})$, organic matter $(\mathrm{OM})$, total nitrogen $(\mathrm{TN}) \mathrm{N}$, soil available nutrients $(\mathrm{P}, \mathrm{K}$ and $\mathrm{S})$ were measured in laboratory. After data normalization, classical and geo-statistical analyses were used to describe soil properties and spatial correlation of soil characteristics. Spatial variability of soil physico-chemical properties was quantified through semi-variogram analysis and the respective surface maps were prepared through ordinary Kriging. Spherical model fits well with experimental semi-variogram of $\mathrm{pH}, \mathrm{EC}, \mathrm{OM}, \mathrm{TN}$, available $\mathrm{P}, \mathrm{K}$ and $\mathrm{S}$. Soil $\mathrm{pH}$, available phosphorus (Av P), potassium (Av K) and sulfur (Av S) have the moderate spatial dependence, with nugget/sill ratios of $41.13 \%$ to $72.21 \%$. The others have the strong dependence with nugget $/$ sill ratios of less than $25 \%$. The spatial variability of estimating soil properties varies within range of 0.0142 for Av $\mathrm{P}$ to 0.0383 for $\mathrm{Av} \mathrm{S}$ and this model can calculate the un-sampled within neighboring distance of about $12.65 \mathrm{~m}$ for Av $\mathrm{S}$ to $150.82 \mathrm{~m}$ for TN, respectively. Cross validation of kriged map shows that spatial prediction of soil nutrients using semi-variogram parameters is better than assuming mean of observed value for any un-sampled location. Therefore, it is a suitable alternative method for accurate estimation of chemical properties of soil in un-sampled positions as compared to direct measurement which has time and costs concerned.
\end{abstract}

Key words: Spatial variability; Soil properties; Semi-variogram; Kriging; Geo-statistical analysis; Nugget/sill ratios; Agricultural fields

\section{Introduction}

Soil parameters are important for evaluating soil quality as well as soil fertility. These parameters of soil are related to variability in different land use pattern and their degradation will result in a decrease of levels of soil fertility, nutrients and thus productivity (Gray and Morant, 2003). It is critical for farmers attempting to increase fertilization efficiency and crop productivity from scientific information concerning spatial variability and distribution of soil properties (Mabit et al., 2008; Tesfahunegn et al., 2011); fertilization based on large scale maps with recommendations related to soil fertility may also lead to reduced fertilizer inputs without reducing yield (Jalali, 2007). Therefore, assessing the spatial variability of soil chemical parameters is crucial to efforts designed to introduce sustainable cropping systems, especially for developing countries such as Bangladesh. Moreover, it should keep in mind that changing one component, one may affect the optimums for others. In understanding those interactions and how to manage them the real value of site-specific management should find out. Responding to those interactions, paying attention to details of the system is the key to profitable implementation of site-specific management. 
Soil variability is the outcome of many processes acting and interacting across a continuum of spatial and temporal scales (Parkin 1993; Cambardella et al., 1994). The variability of soil properties within fields is often described by traditional statistical methods, which assume that variation is randomly distributed within mapping units. Geo-statistical methods, based on the theory of regionalized variables, are more useful tools for describing and understanding the spatial variability of measured variables compared with the traditional statistical methods (Bregt et al., 1992). Semivariograms and kriging statistics have been used extensively to explain and characterize the spatial variability of chemical properties of soils under different cropping patterns (West et al., 1989; Cahn et al., 1994; Cambardella and Karlen, 1999; Borges and Mallarino 1997; Kollias et al., 1999). During the last 10 years, data obtained from GPS (global positioning system), GIS (geographic information system), and geo-statistics have played an important role in the study of soil nutrient spatial variability with respect to soil nutrient site-specific management in some developed countries (Vetsch et al., 1995; Jin, 1998). The results from these countries show that soil variability can occur at any scale, ranging from a few millimeters to large fields of several hectares.

For geostatistical analysis including construction of sample variograms and kriging were performed with the aid of geostatistical software, ArcMap10.0. The degree of spatial dependence for each variable was determined with geostatistical methods using semivariogram analysis and kriging (Mcbratney and Pringle, 1999). Semivariogram is a measure of the dissimilarity. It provides a description of how the data are related (correlated) with distance. The average dissimilarity between data separated by a vector $h$ is measured by the experimental semivariogram $\hat{Y}(h)$, which is computed as half the average squared difference between the components of every data pair (Journel and Huijbregt, 1978).

$$
\gamma(h)=\frac{1}{2 N(h)} \sum_{i=1}^{N(h)}\left[Z_{(i+h)}-Z_{i}\right]^{2}
$$

Where $(h)$ is the number of experimental pairs $\left[\mathrm{Z}_{(i+h),} \mathrm{Z}_{i}\right]$ of data separated by a vector $h$. A semivariogram consists of three basic parameters which describe the spatial structure as $\gamma(\mathrm{h})=\mathrm{Cr}+\mathrm{C}, \mathrm{h} \geq \mathrm{r} . \mathrm{C}_{o}$ represents the nugget effect, which is local variation occurring at scales smaller than the sampling interval, such as sampling error; $\mathrm{C}_{o}+C$ is the sill (total variance); and is the range, at which semivariogram levels off (beyond that distance the variables are not spatially correlated).
The nugget/sill ratio indicates what percent of the overall variance is found at a distance smaller than the smallest lag interval, and gives a sense of how much variance you have successfully accounted for in the model.

Kriging is an interpolation technique that generates the best linear unbiased estimate at each location using the spatial variability obtained from the variogram model. Kriging offers a wide and flexible variety of tools that provide estimates for un-sampled locations using weighted average of neighboring field values falling within a certain distance called the range of influence. Kriging requires a variogram model to compute variable values for any possible sampling interval. The variogram functionality in conjunction with kriging allows us to estimate the accuracy with which a value at an un-sampled location can be predicted given the sample values at other locations (Isaaks and Srivastava, 1989).

The objectives of the research work were to (i) evaluate the spatial variability of selected soil chemical properties of agricultural fields and (ii) characterizing and mapping of spatial variability of selected soil chemical properties.

\section{Methods and materials}

The study area Batiaghata is located at $22.7417^{\circ} \mathrm{N} 89.5167^{\circ} \mathrm{E}$ in Khulna district. Batiaghata upazila consists of 7 union parisads. The Jalma union is the largest union of this upazila. The Kajibacha River splits it into eastern and western part. It has 23698 households and total area $248.33 \mathrm{~km}^{2}$ (BPC, 2001).The main rivers are Kazibachha, Shoilmari, Salta, Jhopjhopia, Pasur, Sibsa, Rupsa and Nalua. Main canals are Aria, Batiaghata and Halia and beels are Jhalma, Jhalbari, Basurabad, Ginirabad, and Bhatgati. Batiaghata (Town) is situated on the banks of the river Kazibachha, $10 \mathrm{~km}$. south from Khulna city and on the west of Khulna-Chalna road (USDA, 2004).

A total of 40 soil samples $(0-25 \mathrm{~cm})$ were collected in the field through random sampling from different locations of Batiaghata Upazila under different cropping patterns (rice, pulse, sesame, ladisfinger, lentil, corn, watermelon, pumpkin, chilli, vegetable, orchard and fallow etc). A portable global positioning system (GPS) was used to record each sample site.Soil samples were collected for laboratory analysis. The samples were placed in plastic bags. The collected samples were all air dried, weighed, and sieved to $2 \mathrm{~mm}$ to separate the coarse $(>2 \mathrm{~mm})$ and fine $(<2 \mathrm{~mm})$ fractions. The sieved soils were then preserved in plastic container and labeled properly. These were later used for chemical analyses. 


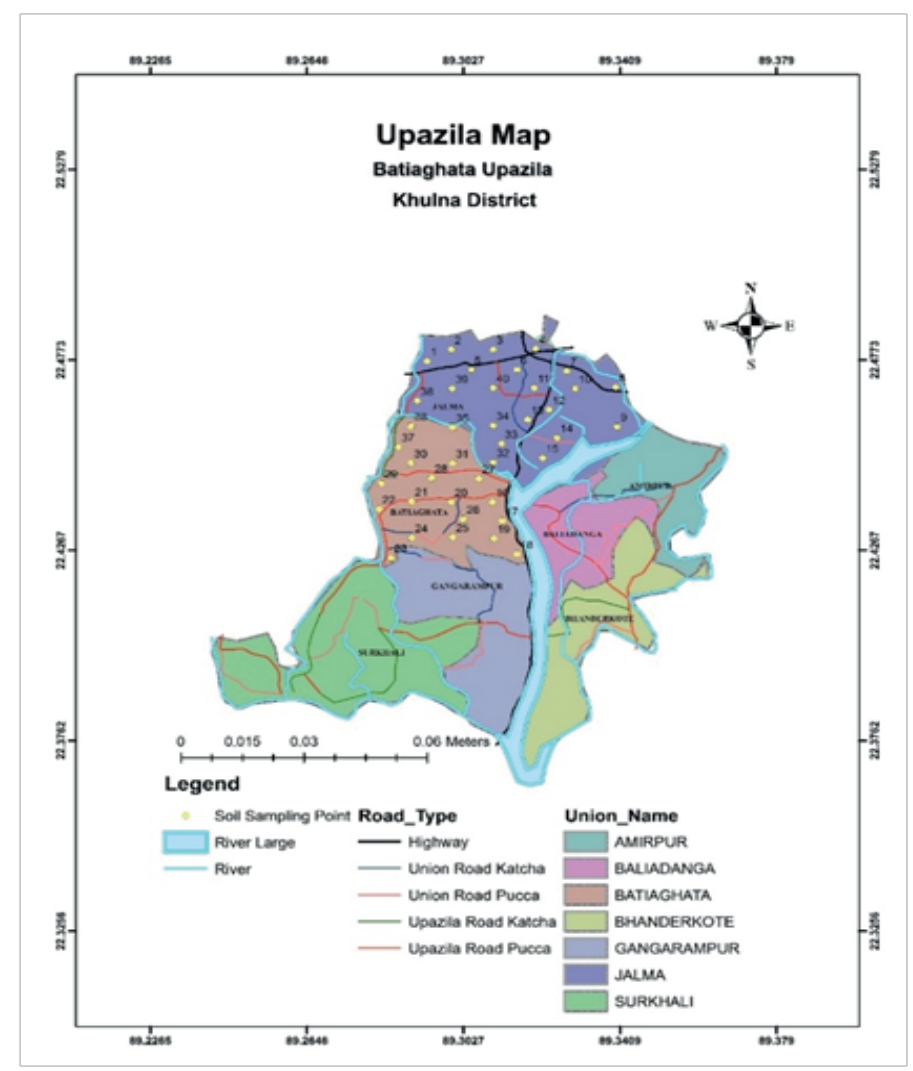

Fig. 1. Batiaghata Upazila Map(LGED, 2010)

The collected soil was sieved through a $2 \mathrm{~mm}$ mesh screen to remove plant roots, rocks, and macro fauna. sieved soil samples were analyzed for chemical properties. Soil $\mathrm{pH}$ was determined electrochemically using glass electrode $\mathrm{pH}$ meter maintaining soil to water ratio 1: 2.5 as suggested by Jackson (1962). The electrical conductivity (EC) to the soil was measured at a soil to water ratio of 1: 5 using EC meter (USDA, 2004). Total nitrogen of the soils was determined by colorimetric method (Bremner and Mulvaney, 1982) following $\mathrm{H}_{2} \mathrm{SO}_{4}$ acid digestion as suggested by Jackson (1967). Available phosphorus was extracted from the soil with 0.5 $\mathrm{M} \mathrm{NaHCO}$ (Olsen Method) at $\mathrm{pH} 8.5$ and Molybdophosphoric blue colour method of analysis was employed for determination (Murphy and Riley, 1962). The available $\mathrm{K}$ was determined from $\mathrm{NH}_{4} \mathrm{OAc}(\mathrm{pH}$ 7.0) extract as described by Jackson (1967). The extract was analyzed for available K by a flame analyzer at 589 nm (Jackson, 1967). Available sulphur content was determined by turbidimetric method as described by Jackson (1973). It was measured by spectrophotometer at $420 \mathrm{~nm}$. Organic carbon of samples was determined by Walkley and Black's wet oxidation method as outlined by Jackson (1962).

\section{Statistical analysis}

Using SPSS classical statistics (mean, median, standard deviation and standard error of mean, skewness and kurtosis) were calculated for all soil parameters. Prior to construction of variograms, the data were tested for normality.For geostatistical analysis including construction of sample variograms and kriging were performed with the aid of geostatistical software, ArcMap10.0. The degree of spatial dependence for each variable was determined with geostatistical methods using semivariogram analysis and kriging (Mcbratney and Pringle, 1999).

\section{Results and discussion}

\section{Explanatory statistical analysis}

The summary of descriptive statistics for soil parameters are shown in Tables I. The parameter values strongly varied between fields. Mean and median values of the majority of soil parameters measured at the study area were similar, with median values generally slightly higher than the means (Table 1), indicating dominant measures of central tendency. This similarity was also noted by many other researchers, including Brejda et al. (2000), Cambardella and Karlen (1999), Cambardella et al. (1994), Emadi et al. (2008) and Young et al. (1999).

$\mathrm{pH}$ of the soil ranged from 5.30 to 8.0 and with a mean $(\mu)$ value of 7.35 and standard deviation $(\sigma)$ of 0.54 of the studied area. $\mathrm{pH}$ followed a normal distribution indicated by the Kurtosis and skewness coefficient. This neutral to slightly alkaline soil reaction $(\mathrm{pH})$ is a common feature of Ganges tidal floodplain and Ganges alluvial floodplain soils of Bangladesh (Lake,2000). That value of $\mathrm{pH}$ might be a result of application of different types of fertilizers at the surface soil at varying amount. The no tillage soils had a higher soil $\mathrm{pH}$ values than plow tillage soils (Chatterjee et al., 2009).

EC of the studied area was found between the ranges 1.5 to $15.8 \mathrm{dSm}^{-1}$. Mean $(\mu)$ and standard deviation $(\sigma)$ of EC was $7.21 \mathrm{dSm}^{-1}$ and 2.93 respectively (Table I). Maximum areas are saline soil as there is littoral deposition of estuarial intrusion of brackish tidal water from sea through creeks (Lake, 2000; USDA,2016). Most of the areas which are located at the cannel side contain highly saline soil. EC varies with the concentration of dissolved salts (Bohn et al., 1985), and usually $\mathrm{pH}$ decreases when the salt concentration increases (Seatz and Peterson, 1965). Moreover, soil EC could be related to other soil properties such as water holding capacity, topsoil depth, soil nutrients levels, salinity, and subsoil characteristics.

Soil organic matter (SOM) ranged from 1.33 to $4.41 \%$. Mean $(\mu)$ and standard deviation $(\sigma)$ of SOM is $2.53 \%$ and 0.68 
respectively (Table I). Vegetable, pulse, and fallow land conserve more SOM than agricultural field (Table I). Soil organic matter was higher at no-tillage soils compared with minimum tillage with chisel plow and conventional tillage with mouldboard plow (Lopez-Fando and Pardo, 2011). Some researchers reported that the highest OM content was found in grasslands compared to agricultural fields (Riezebos and Loerts, 1998; Paz-Gonzalez et al., 2000; Jaiyeoba, 1995). The depletion of organic matter in the cultivated fields can be associated with the intensive tillage and the removal of plant residue.

Total nitrogen of the sample showed comparatively lower values within the range of 0.09 to 10.27 with a mean value of $0.141 \%$. These results might be associated with tiny fertilizer applications in recent decades (Liu et al., 2013). The values showed a positive skewness and leptokurtic in nature.

The values of available phosphorus (Av P) showed leptokurticity. Available phosphorus content of the studied plot was low within the range of 1.35 to 14.55 and with a mean value of $6.33 \mathrm{ppm}$ compared to standard and this might be related to balanced $\mathrm{P}$ fertilizer application (Gao et al., 2001). For regions with high soil $P\left(>10 \mathrm{mg} \mathrm{kg}^{-1}\right)$, additional $\mathrm{P}$ fertilizer was needed because of its strong after effects and the high soil temperatures increasing $\mathrm{P}$ availability during rice growing season (Bruun et al., 2006). Lienwber and Schulten (1998) estimated that the amount and type of clay mineralogy in the soil affects $\mathrm{P}$ availability.

Available sulfur (Av S) content showed highly variable with a range of 30.2 to 423.6 with a mean value of $2.62 \mathrm{ppm}$. It showed leptokurtic in nature and a normal distribution, as indicated by the Kurtosis and skewness coefficient. This high range might be due to comparatively low washed out $\mathrm{S}$ in the form of sulphates, especially under leaching conditions (Vanek et al., 2008).

The coefficient variation $(\mathrm{CV})$ is the ratio of the standard deviation (SD) to the mean values times 100 . Three outof seven soil properties a CV greater than $30 \%$, demonstrating substantial variability within the datasets (Table I). The highest and the least CVs for soil parameters were obtained for Av $\mathrm{P}(54.19 \%)$ and $\mathrm{pH}(7.35 \%)$ respectively, indicating the high variability for Av $\mathrm{P}$ relative to other soil parameters (Weindorf and Zhu, 2010). SOM had a relatively high CV of $26.88 \%$, which could be linked to heterogeneity in the land-use pattern, fertilizer application, or erosion. In addition, the higher $\mathrm{CV}$ of the EC (40.64\%) could be the consequence of agricultural practices such as soil tillage, fertilization, and vertical distribution of finer materials, the removal of nutrients by plants, and the changes of soil water balance.

Results showed there is lower value of skewness and kurtosis among soil parameters $(\mathrm{pH}$, electrical conductivity, and organic matter, extractable elements such as available $\mathrm{K}, \mathrm{P}$ and $\mathrm{S}$ as well as total $\mathrm{N}$ )due to intrinsic characteristics of variables, environmental conditions like human activities, sampling methods and number of samples.

\section{Correlations among selected soil parameters}

To characterize the relationships between yield and selected soil chemical properties(organic matter, $\mathrm{pH}$, available sulfur,

Table I. Descriptive statistics for selected chemical soil parameters

\begin{tabular}{lccccccccc}
\hline Properties & Min & Max & Mean & Median & SD & Variance & $\begin{array}{c}\text { CV } \\
(\%)\end{array}$ & Skewness & Kurtosis \\
\hline pH & 5.3 & 8 & 7.35 & 7.5 & 0.54 & 0.29 & 7.35 & -1.695 & 4.166 \\
EC $\left(\mathrm{dSm}^{-1}\right)$ & 1.5 & 15.8 & 7.21 & 7.2 & 2.93 & 8.591 & 40.64 & 0.246 & 0.793 \\
OM (\%) & 1.33 & 4.41 & 2.53 & 2.21 & 0.68 & 0.458 & 26.88 & 0.755 & 0.228 \\
Total N\% & 0.09 & 0.27 & 0.141 & 0.13 & 0.04 & 0.001 & 28.37 & 1.225 & 1.666 \\
Av P (ppm) & 1.35 & 14.55 & 6.33 & 5.96 & 3.43 & 11.79 & 54.19 & 0.498 & -0.405 \\
Av K (ppm) & 0.41 & 1.02 & 0.56 & 0.51 & 0.144 & 0.021 & 25.71 & 1.535 & 2.052 \\
Av S (ppm) & 30.2 & 423.6 & 2.62 & 2.83 & 1.086 & 1.179 & 41.45 & -0.415 & -1.011
\end{tabular}

$\mathrm{CV}(\%)=\frac{\sigma}{\mu} \times 100$

(Where, $\mathrm{CV}=$ coefficient of variation, $\sigma=$ standard deviation, $\mu=$ mean) 
total nitrogen, available phosphorus, available potassium, and electrical conductivity), Pearson's product moment correlation coefficient was calculated for each property (Table II). values can be estimated through kriging (using modeled semivariogram parameters) at unsampled locations was tested using different error estimates.Model parameters for

Table II. Correlations among selected soil parameters

\begin{tabular}{|c|c|c|c|c|c|c|c|c|}
\hline & & $\mathrm{pH}$ & $\begin{array}{c}\mathrm{EC} \\
\left(\mathrm{dSm}^{-1}\right)\end{array}$ & $\begin{array}{l}\text { OM } \\
(\%)\end{array}$ & $\begin{array}{c}\text { Total N } \\
(\%)\end{array}$ & $\begin{array}{l}\text { Av P } \\
(\mathrm{ppm})\end{array}$ & $\begin{array}{l}\mathrm{Av} \mathrm{K} \\
(\mathrm{ppm})\end{array}$ & $\begin{array}{l}\text { Av S } \\
(\mathrm{ppm})\end{array}$ \\
\hline $\mathrm{pH}$ & $\begin{array}{l}\text { Pearson } \\
\text { Correlation }\end{array}$ & 1 & & & & & & \\
\hline $\mathrm{EC}\left(\mathrm{dSm}^{-1}\right)$ & $\begin{array}{l}\text { Pearson } \\
\text { Correlation }\end{array}$ & $-.427^{* *}$ & 1 & & & & & \\
\hline $\mathrm{OM}(\%)$ & $\begin{array}{l}\text { Pearson } \\
\text { Correlation }\end{array}$ & -.258 & .278 & 1 & & & & \\
\hline Total N (\%) & $\begin{array}{l}\text { Pearson } \\
\text { Correlation }\end{array}$ & -.230 & .233 & $.935^{* *}$ & 1 & & & \\
\hline Av P (ppm) & $\begin{array}{l}\text { Pearson } \\
\text { Correlation }\end{array}$ & $.335^{*}$ & -.039 & -.013 & .028 & 1 & & \\
\hline Av K (ppm) & $\begin{array}{l}\text { Pearson } \\
\text { Correlation }\end{array}$ & $-.493^{* *}$ & $.344^{*}$ & .246 & .263 & .058 & 1 & \\
\hline Av S (ppm) & $\begin{array}{l}\text { Pearson } \\
\text { Correlation }\end{array}$ & $-.330^{*}$ & $.540^{* *}$ & .269 & .307 & .043 & .224 & 1 \\
\hline
\end{tabular}

** Correlation is significant at the 0.01 level (2-tailed).

* Correlation is significant at the 0.05 level (2-tailed).

Correlations were found to be highly significant between some variables as generally reported e.g., organic matter and total nitrogen $\left(r^{2}=0.935\right)$, electrical conductivity and available sulfur $\left(r^{2}=0.540\right)$. Significant correlations can also be identified between $\mathrm{pH}$ and available phosphorus $\left(\mathrm{r}^{2}=0.335\right)$. It is clear that soil $\mathrm{pH}$ was strongly negatively correlated with electrical conductivity $\left(r^{2}=-0.427\right)$ and available potassium $\left(\mathrm{r}^{2}=-0.493\right)$. Moreover, no significant correlation was observed between organic matter and other properties.

\section{Geostatistical analysis}

\section{Semivariogram and spatial dependency}

Soil samples from over 40 locations are needed to properly detect anisotropy (Robinson and Metternicht, 2006); hence, it was not feasible to explore directional effects for the data set used in this study. Hence, variogram models were assumed to follow the isotropy and only isotropic variogram models were considered for this study. The accuracy of soil property the best fit semivariogram models are presented in Table III. A large range indicates that the observed values of a soil variable are influenced by other values for this variable over greater distances than soil variables, which have smaller ranges (Lopez-Granados et al., 2002).

Several models are used for semivariogram analysis. Spherical model used to calculate the theoretical semivariogram parameter in ArcGIS 10.0. The nugget value represents the random variation usually derived from the in accuracy of measurements or variations of the properties that cannot be detected in the sample range (Trangmar et al., 1985). The sill value is the upper limit of the fitted semivariogram model (Webster and Oliver, 2001). The ratio of nugget to sill indicates the spatial dependency of the soil properties. The range of the semivariogram represents the average distance through which the variable semivariance reaches its peak value. A small effective range implies a distribution pattern composed of small patches (Zhou et al., 2010). 
Table III. Semivariogram model parameters for soil properties

\begin{tabular}{cccccccc}
\hline $\begin{array}{c}\text { Soil } \\
\text { properties }\end{array}$ & $\begin{array}{c}\text { Model } \\
\text { type }\end{array}$ & Nugget & Sill & $\begin{array}{c}\% \\
\text { Nugget* }\end{array}$ & $\begin{array}{c}\text { Spatial } \\
\text { Class** }\end{array}$ & $\begin{array}{c}\text { Direction } \\
(\mathrm{m})\end{array}$ & Range \\
\hline $\mathrm{pH}$ & Spherical & 0.0017 & 0.0042 & 41.13 & Moderate & 73.1 & 0.0383 \\
EC $\left(\mathrm{dSm}^{-1}\right)$ & Spherical & 0 & 0.2667 & 0 & Strong & 16.2 & 0.0224 \\
OM (\%) & Spherical & 0.0073 & 0.0442 & 16.50 & Strong & 64.51 & 0.0233 \\
Total N (\%) & Spherical & 0.0136 & 0.0323 & 42.29 & Moderate & 150.82 & 0.0188 \\
Av P & Spherical & 0.1619 & 0.2932 & 55.22 & Moderate & 141.68 & 0.0142 \\
Av K & Spherical & 0.0186 & 0.0452 & 41.26 & Moderate & 56.95 & 0.0171 \\
Av S & Spherical & 0.1957 & 0.2711 & 72.21 & Moderate & 12.65 & 0.0383 \\
\hline
\end{tabular}

$* \%$ Nugget $=($ nugget semivariance $/$ total semivariance $) \times 100$.

$* *$ Strong $=\%$ Nugget $<25 \%$; Moderate $=\%$ Nugget $25-75 \%$; Random $=\%$ Nugget $>75 \%$ (Cambardella et al., 1994)

The nugget effect can be defined as an indicator of the continuity at close distances. Soil properties with lower nugget effect were generally defined by spherical semivariogram model (Table III). The soil parameters including $\mathrm{pH}$, available sulfur, total nitrogen, available phosphorus and available potassium follow a moderate spatial distribution (except organic matter and electrical conductivity) and clear patchy distribution all over the studied area as the percent nugget value includes $41.13 \%$, $72.21 \%, 42.29 \%, 52.22 \%$ and $41.26 \%$, respectively (Table III) and (Fig. 1). The spatial variability of estimating soil properties varies within range of 0.0383 for $\mathrm{pH}, 0.0224$ for EC, 0.0233 for OM, 0.0188 for Total N, 0.0142 for Av P, 0.0171 for Av K and 0.0383 for Av S and this model can calculate the unsampled within neighboring distance of about $73.1 \mathrm{~m}$ for $\mathrm{pH}, 16.2 \mathrm{~m}$ for EC, $64.51 \mathrm{~m}$ for OM, $150.82 \mathrm{~m}$ for Total N, $141.68 \mathrm{mfor} \mathrm{Av} \mathrm{P,} 56.95 \mathrm{~m}$ for Av K and $12.65 \mathrm{~m}$ for Av S,respectively. Their spatial dependence may be controlled by both intrinsic variations of soil properties and extrinsic factors such as human induced activities (Liu et al., 2013; Wu et al., 2010).

\section{Spatial distribution of soil parameters}

Soil parameter maps obtained by ordinary kriging interpolation were displayed in Fig. 2(a) to Fig. 2(g). The results showed that all the soil samples varied considerably all over the studied area. The spatial variation in soil parameters should not be surprising, since the values of the variables are usually the result of an intrinsic variation in soil properties and management practices as previously reported by Mallarino et al. (1999).
A low ratio $(<25 \%)$ means that a large part of the variance is introduced spatially, implying a strong spatial dependency of the variable. When the distribution of soil properties is strongly or moderately spatially correlated, the average extent of these patches is given by the range of the semivariogram. Again if the ratio was $100 \%$, or the slope of the semivariogram was close to zero, the soil variable was considered non-spatially correlated (pure nugget). Their spatial dependence might be controlled by both intrinsic variations of soil properties and extrinsic factors such as human induced activities (Liu et al., 2013; Wu et al., 2010). However, unknown spatial dependency of the variable could exist at a lower scale even if a high nugget/sill percentage was obtained (Wu et al., 2008).

The soil parameter $\mathrm{pH}$ follows a moderate spatial distribution and clear patchy distribution all over the studied area. $\mathrm{pH}$ of the soil was higher in the western part of the study area, while lower $\mathrm{pH}$ was found at southern site of the study area. Samples in the Fig. 2(a) were generally characterized by having extensive areas with $\mathrm{pH}$ levels 7.6 to 7.7 indicating mildly alkaline $\mathrm{pH}$. Lake (2000) observed that in the relative absence of acidic cations, $\mathrm{pH}$ may rise above 7 and $\mathrm{pH}$ change with current agricultural practices.

EC of the soil is higher in the south east site as shown in the Fig. 2(b), where there has a scope of large amount of littoral deposition of estuarial intrusion of brackish tidal water from river through creeks and possess slightly saline soil. The important changes occurred in soil properties with cultivation. Soil degradation increased with soil tillage and rapidly deteriorated soil fertility by decreasing OM. 

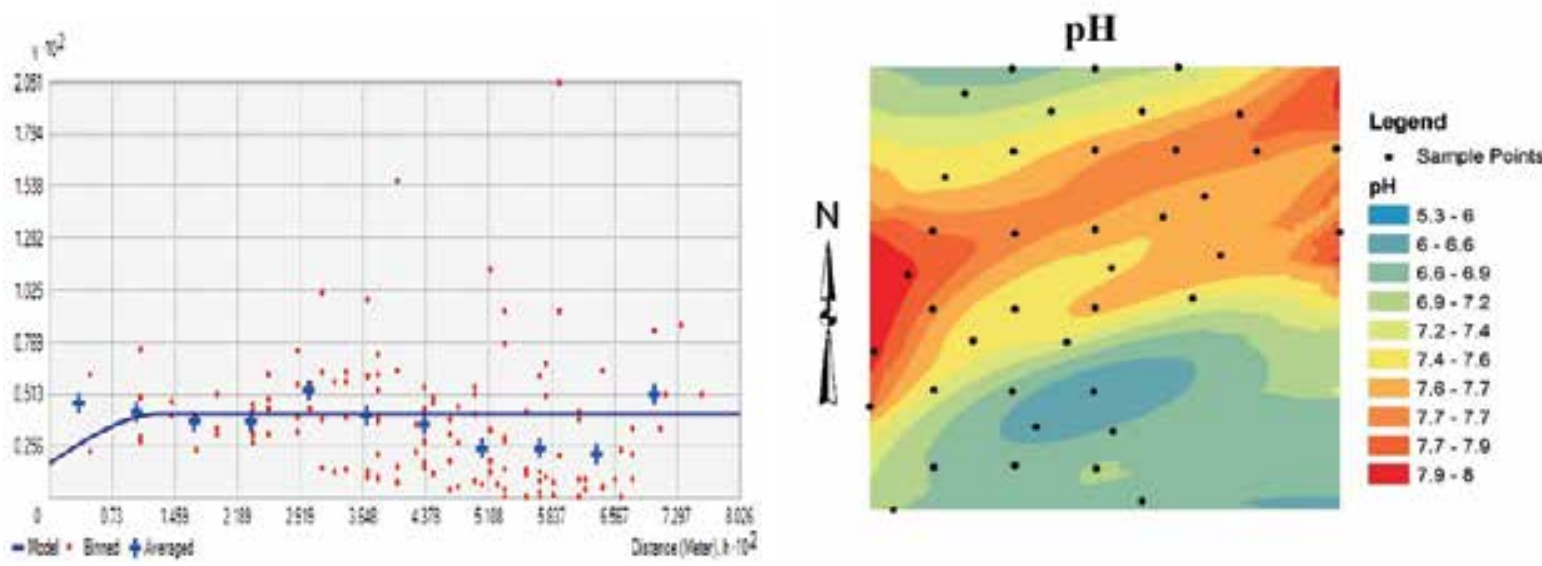

Model: $0.00172 *$ Nugget $+0.0025 *$ Spherical $(0.0383,0.0128,73.1)$
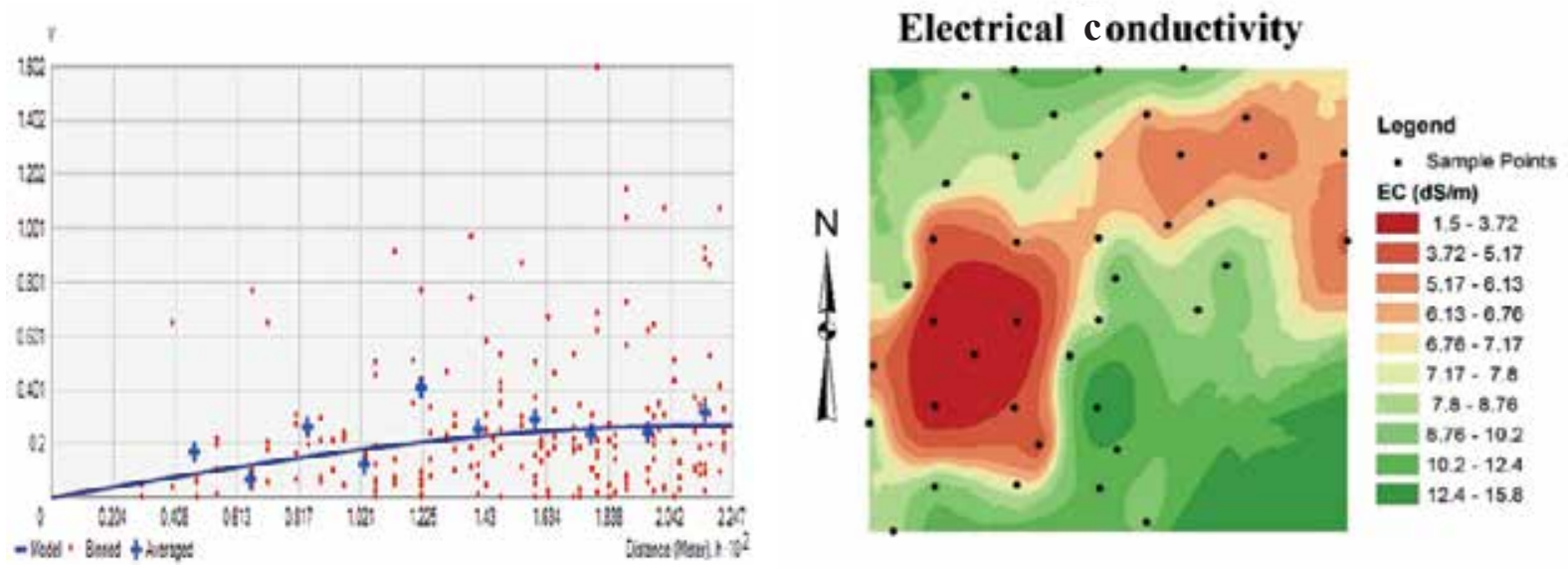

Model: $0 *$ Nugget $+0.2667 *$ Spherical $(0.0224,0.0134,16.2)$
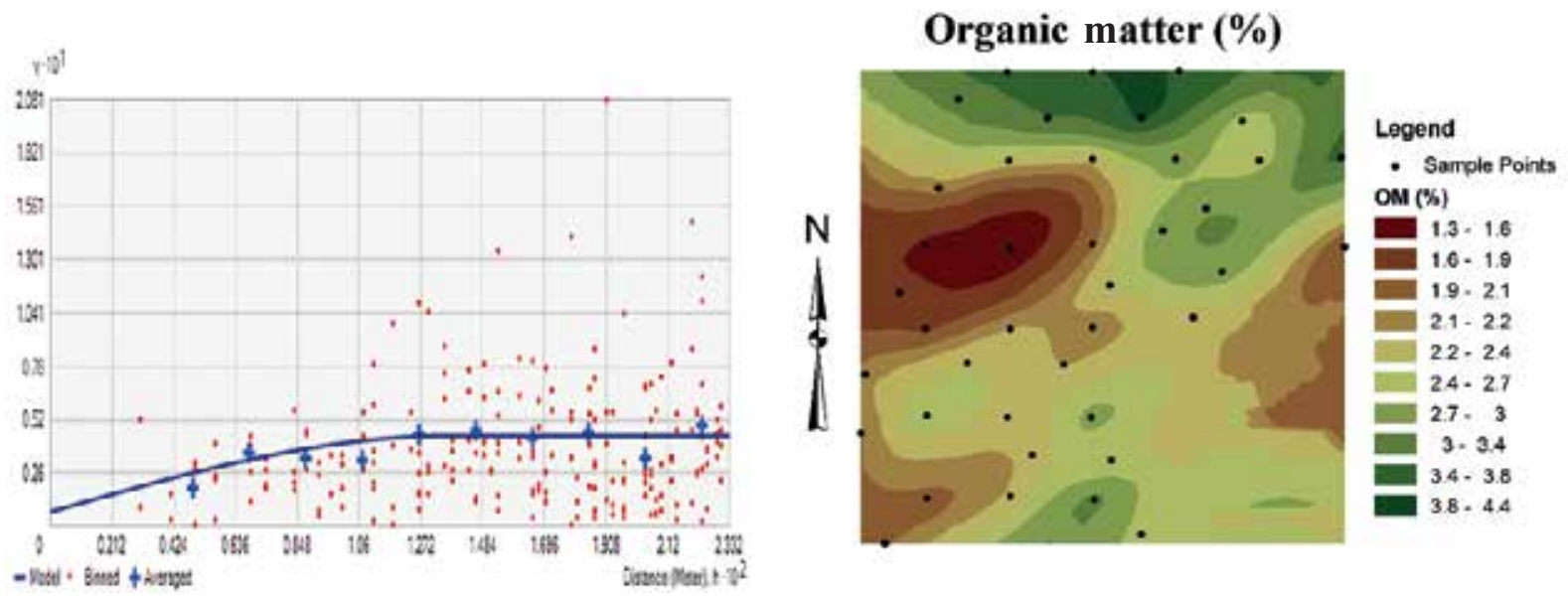

Model: $0.0073 *$ Nugget $+0.0369 *$ Spherical $(0.0233,0.0128,64.5)$

Fig. 2. Semivariograms and kriged maps of soil (a) pH, (b) EC and (c) OM 

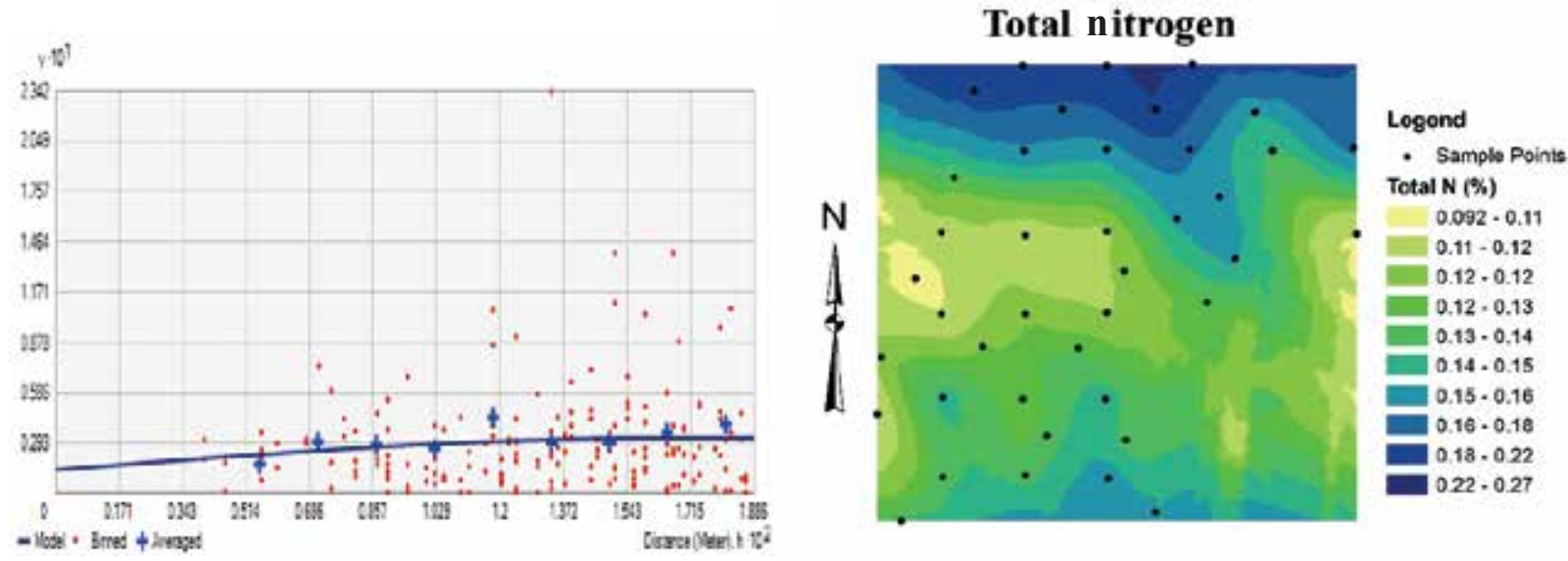

Model: $0.0136 *$ Nugget $+0.0187 *$ Spherical $(0.0188,0.0128,150.8)$
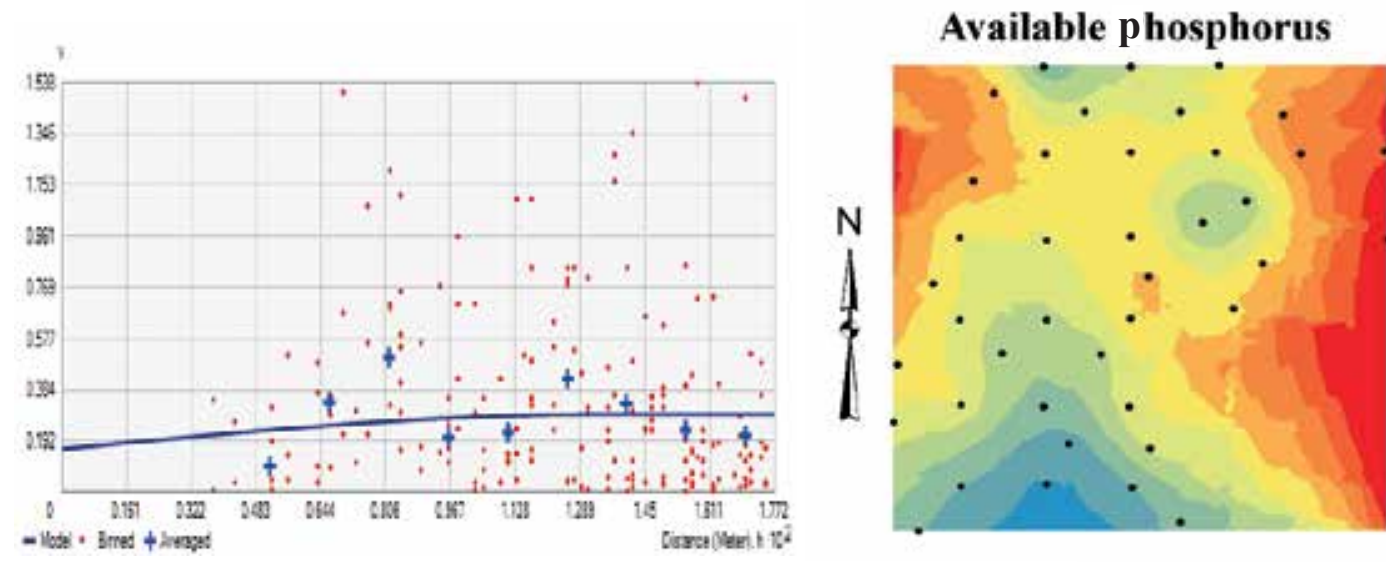

\section{Legend}

- Sample Ponts Available $\mathbf{P}(\mathbf{p p m})$ $1.35-2.08$ $2.08 \cdot 2.89$ $2.80 \cdot 3.82$ $3.82=4.88$ $4.86 \cdot 6.03$ 6.03 .7 .35 $7.35-8.84$ $8.84 \cdot 105$ $10.5-12.4$ $12.4 \cdot 14.6$

Model: $0.1619 *$ Nugget $+0.1313 *$ Spherical $(0.0142,0.013,141.68)$
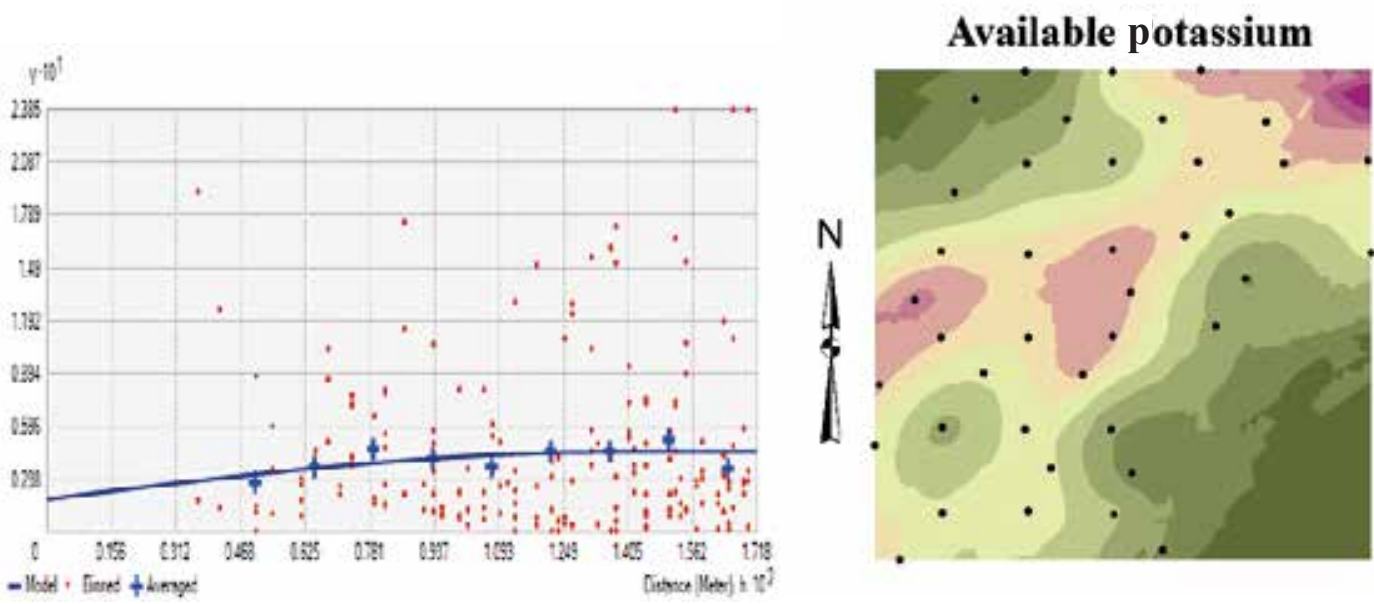

Legend

- Sample Poirts Available K (ppm) $0.41=0.43$

$0.43=0.44$ $0.44-0.45$

$0.45 \cdot 0.47$ $0.47 \cdot 0.5$ $0.5-0.55$ $0.55-0.61$ ㅁ. $0.61-0.7$

짐 $0.7-0.83$ - $0.83 \cdot 1$

Model: $0.0186 *$ Nugget $+0.0266 *$ Spherical $(0.0171,0.0128,56.95)$

Fig. 2. Semivariograms and kriged maps of soil (d) Total N, (e) Av P and (f) Av K 
Therefore, a sustainable soil management system should be applied to decrease soil degradation (Acquaah, 2002).

Higher percentage of $\mathrm{OM}$ was observed in the northeast part of the study area, while low percentage of OM was found at middle point of the study area. Samples were generally characterized by having extensive areas with OM concentrations between 2.2 to $2.4 \%$ in the Fig. 2(c). The semivariograms and kriged map of OM show similar (strong) spatial distribution trend as EC. The Variability of soil OM might be result of landscape attributes including slope, aspect and elevation, and land use might be the dominant factors of SOM in an area with the same parent material and the same climate (Rezaei and Gilkes, 2005).

The spatial distribution trend of total nitrogen was totally similar from OM, as indicated in Table 2. From the correlation table it was found that total nitrogen and OM are strongly correlated positively. Soils were generally characterized by having extensive areas with total nitrogen between $0.13 \%$ and $0.14 \%$ in the Fig. 2 (d) found all over the study area. Meanwhile high levels of total nitrogen was found only at north site. The moderate spatial dependency (Table 3) in total nitrogen levels in different land use pattern might be benefitted from the use of NPK fertilizers, while grassland restoration is frequently encouraged by planting $\mathrm{N}$ fixing alfalfa (Wang et al., 2009).
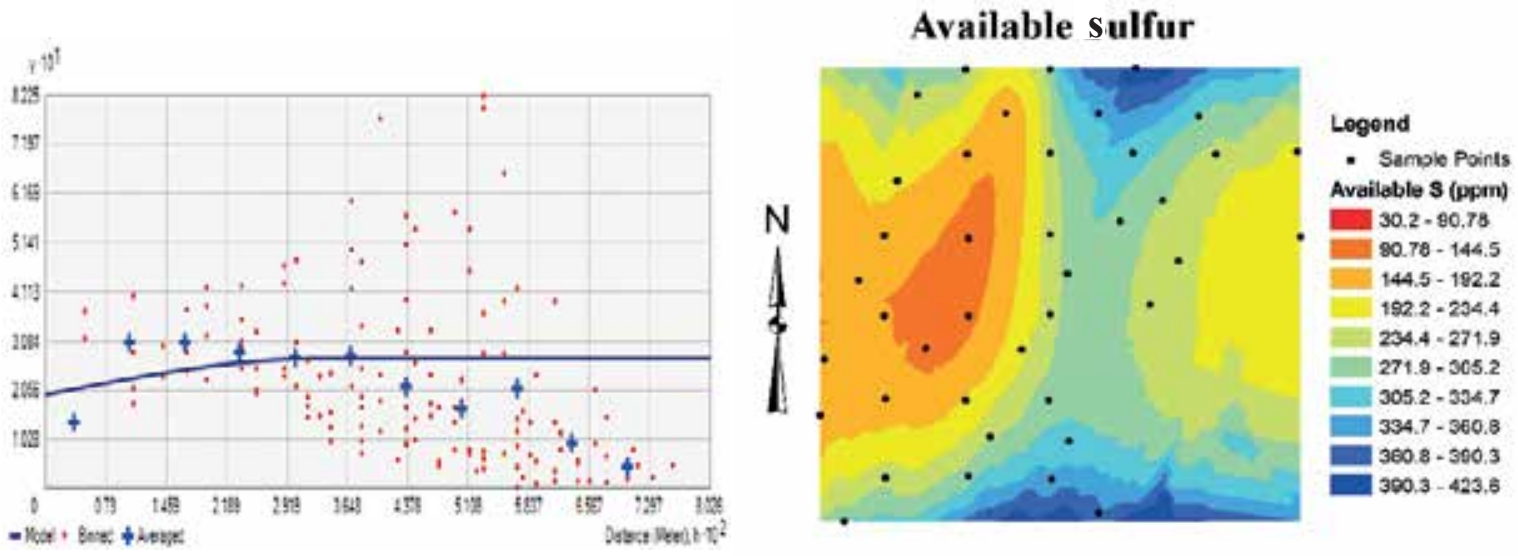

areas with available phosphorus concentrations between 6.03 and $7.35 \mathrm{ppm}$ in the Fig. 2(e). This might be related to unbalanced $P$ fertilizer application (Gao et al., 2001) and also because of animal manure application with different amendments (Fu et al., 2010; Rehm et al., 1994; Islam, 2010).

Relatively high available potassium was observed in the southeast part of the study area, while relatively low available potassium was found at northeast site. Samples were generally characterized by having extensive areas with available potassium concentrations between 0.61 and 0.70 ppm in theFig. 2(f). The distribution of available potassium moderately spatially correlated (Table 3 ), implies that a large part of the variance is introduced spatially. This spatial variability for soil potassium might be due to regional factors (e.g. topography, climate and soil matrix) (Huang et al., 2006). The low application rate of $\mathrm{K}$ fertilizer and intensive cropping system were the two major reasons causing the observed severe potassium depletion (Lu et al., 2000; Zhang et al., 2010).

Model: $0.1957 *$ Nugget $+0.0753 *$ Spherical $(0.0383,0.0128,12.65)$

Available sulfur of the soil was higher in the southern part of the study area, while relatively low amounts of available sulfur was found at middle point of the study area. Soils were generally characterized by having extensive areas with

Model: $0.1957 *$ Nugget $+0.0753 *$ Spherical $(0.0383,0.0128,12.65)$

Fig. 2. Semivariograms and kriged maps of soil (g) Av S

Available phosphorus of the soil follows a moderate spatial distribution and clear patchy distribution all over the studied area.Available phosphorus of the soil was higher in the eastern part of the study area, while relatively low amounts of available phosphorus was found at southern site of the study area.Soils were generally characterized by having extensive available sulfur concentrations between 234.4 to $271.9 \mathrm{ppm}$ in the Fig. 2(g). The low amounts of sulfur level might be a result of mostly washed out sulfur in the form of sulphates, especially under leaching conditions (Vanǵk et al.,2008). 


\section{Summary and conclusion}

Thus, descriptive statistics indicated the sizeable spatial variability for all soil variables. Further understanding of the spatial structures of soil variables can be helpful for revealing their spatial distribution and achieving the reasonable site specific farming management. The geo-statistical analysis of soil variables suggested that the value nugget-sill ratio ranges from $0 \%$ (EC) to $55.22 \%$ (Av P), except for available sulfur (72.21\%), indicating that internal factors were dominant over external factors. Soil EC and OM had the strong spatial dependence with a nugget-sill ratio of $<25 \%$, because it induced by structural factors. But the spatial variability of other soil variables ( $\mathrm{pH}, \mathrm{TN}, \mathrm{Av} \mathrm{P}, \mathrm{Av} \mathrm{K}$ and $\mathrm{Av} \mathrm{S})$ had the moderate spatial dependence with a nugget-sill ratio of $25-75 \%$, because the variables were mainly determined by internal and external factors. The spatial correlation distances of all variables varied from $16.2 \mathrm{~m}$ (EC) to $150.82 \mathrm{~m}(\mathrm{TN})$, indicating that the sampling design is reasonable. Distribution maps, derived by kriging interpolation, illustrated that these studied area were characterized by moderate to high value of electrical conductivity (EC) and available potassium in southeast site. Available phosphorus and soil $\mathrm{pH}$ varied all over the studied area, where as total nitrogen and organic matter had high percentage at the northeast corner. The areas with low soil organic matter concentrations (1.3-1.6\%) and available sulfur (30.2- $90.78 \mathrm{ppm}$ ) were mainly located in middle point of the study area. Notably available phosphorus showed a different trend in spatial distribution from south to north site. These results are reflection of many factors including soil $\mathrm{pH}, \mathrm{CEC}, \mathrm{OC}$, amount of moisture held by soil particles, fertilizer application, animal manure application with different amendments, intensive cropping system, different land use pattern, topography of the field at different weather condition and texture percentage.

\section{References}

Acquaah G (2002), Principles of Crop Production: Theory, Techniques, and Technology. Pearson Education Inc., Upper Saddle River, New Jersey.

BPC (Bangladesh Population Census) (2001), Bangladesh Bureau of Statistics. Cultural survey report of Batiaghata Upazila.

Bohn HL, McNeal BL and OConnor GA (1985), Soil Chemistry, $2^{\text {nd }}$ Ed., Wiley, New York.

Borges R and Mallarino AP (1997), Field-scale variability of phosphorus and potassium uptake by no-till corn and soybean, Soil Science Society of American Journal 61: 846-853. DOI:org/10.1023/B:PRAG.000
Bregt AK, Stoorvogel JJ, Bounma J and Stein A (1992), Mapping ordinal data in soil survey: A Costa Rican example, Soil Science Society of American Journal 56: 525-531.

Brejda JJ, Moorman TB, Smith JL, Karlen DL, Allan DL and Dao TH (2000), Distribution and variability of surface soil properties at a regional scale, Soil Science Society of American Journal 64: 974-982.

Bremner JM and Mulvaney CS (1982), Nitrogen-total In: Methods of Soil Analysis. Part II. Eds. Page et al. $2^{\text {nd }}$ Ed., American Society of Agronomy, Madison, Wisconsin, USA 09: 595-624. doi.org/10.4236/ oalib. 1100971

Bruun, T.B.; Mertz, O. and Elberling, B. (2006). Linking yields of upland rice in shifting cultivation to fallow length and soil properties, Agriculture, Ecosystems and Environment 113: 139-149. doi: 10.1016/j.agee.2005.09.012

Cahn MD, Hummel JW and Brouer BH (1994), Spatial analysis of soil fertility for site-specific crop management, Soil Science Society of American Journal 58: 1240-1248. doi:10.2136/sssaj1994. $03615995005800040035 \mathrm{x}$

Cambardella CA and Karlen DL (1999), Spatial analysis of soil fertility parameters, Precision Agriculture 1: 5-14. doi.org/10.1023/A:1009925919134

Cambardella CA, Moorman TB, Novak JM, Parkin TB, Karlen DL, Turco RF and Konopka AE (1994), Field scale variability of soil properties in central Iowa soils, Soil Science Society of American Journal 58: 1501-1511. doi.org/10.2136/sssaj1994.0361599500 $5800050033 \mathrm{x}$

Chatterjee AR, Lal RK, Shrestha and Ussiri DAN (2009), Soil carbon pools of reclaimed minesoils under grass and forest land uses, Land Degradation \& Development, 20(3): 300-307. doi.org/10.1002/1dr.916

Emadi M, Baghernejad M, Emadi M and Maftoun M (2008), Assessment of some soil properties by spatial variability in saline and sodic soils in Arsanjan Plain, Sourthen Iran, Pakistan Journal Biological Science 11(2): 238-243. doi.org/10.3923/pjbs.2008.238.243

Fu W, Tunney H and Zhan C (2010), Spatial variation of soil nutrients in a dairy farm and its implications for site-specific fertilizer application, Soil and Tillage Research 106: 185-193. 
Gao XZ, Ma WQ, Du S, Zhang FS and Mao DR (2001), Current status and problems of fertilization in China, China Journal of Soil Science 6: 258-261. DOI:org/10.1371\%2Fjournal.pone.0112273

Gray LC and Morant P (2003), Reconciling indigenous knowledge with scientific assessment of soil fertility changes in southeast Burkina Faso, Geoderma 111: 425-437.

Huang S, Jin J, Yang L and Bai Y (2006), Spatial variability of soil nutrients and influencing factors in a vegetable production area of Hebei province in China, Nutrient Cycling in Agro-ecosystems 75: 201-212.

Isaaks EH and Srivastava RM (1989), An Introduction to Applied Geostatistics, Oxford University Press, New York, USA. p 542.

Islam MS (2010), Project report on Assessment of Spatial Variability of Soil Physical, Chemical and Biological Quality, University grand commission, Bangladesh.

Jackson ML (1962), Soil Chemical Analysis, Prentice Hall, Inc., Englewood cliffs, New Jersey, USA.

Jackson ML (1967), Soil Chemical Analysis, Prentice Hall of India Pvt. Ltd. New Delhi, pp 498.

Jackson ML (1973), Soil Chemical Analysis, 2 ${ }^{\text {nd }}$ Ed. Prentice-Hall Inc, Englewood Cliffs, New Jersey, USA.

Jaiyeoba IA (1995), Changes in soil properties related to different land uses in part of the Nigerian semi-arid Sa-vannah, Soil Use and Management 11: 84-89. DOI:org/10.1111/j.1475-2743.1995.tb00501.x

Jalali M (2007), Spatial variability in potassium release among calcareous soils of western Iran, Geoderma 140: 42-51. doi: 10.1016/j.geoderma.2007.03.013

Jin JY (1998), Precision agriculture and its perspective in China (in Chinese), Plant Nutrient and Fertilizer Science 4: 1-7.

Journel AG and Huijbregts CJ (1978), Mining Geostatistics,Academic Press, London, UK.

Kollias VJ, Kalivas DP and Yassoglou NJ (1999), Mapping the soil resources of a recent alluvial plain in Greece using fuzzy sets in a GIS environment, European Journal of Soil Science 50: 261-273. DOI:org/10.1046/j.1365-2389.1999.t01-1-00231.x

Lake B (2000), Understanding soil pH. New South Wales Acid Soil Action Program, Depertment of Agriculture, Retrived on july 12, 2015. Web (URL: http://www.dpi. nsw.gov.au/_data/assets/pdf_file/0003/167187/soil-ph.pdf).
Lienwber P and Schulten HR (1998), Non-hydrolyzable organic nitrogen in soil size separates from long-term agricultural experiments, Soil Science Society of American Journal 62: 383-393.

Liu ZP, Shao MA and Wang YQ (2013), Spatial patterns of soil total nitrogen and soil total phosphorus across the entire Loess Plateau region of China, Geoderma 197-198: 67-78. DOI:org/10.1016/j.geoderma.2012.12.011

Local Government Engineering Department (LGED), (2010). Map of Batiaghata Upazila of Khulna District, Bangladesh, On-line document.

Lopez-Fando C and Pardo MT (2011), Soil carbon storage and stratification under different tillage systems in a semi-arid region, Soil \& Tillage Research 111: 224-230. doi: 10.1016/j.still.2010.10.011

Lopez-Granados F, Jurado-Exposito M, Atenciano S, Garcia-Ferrer A, Sanchez-de-la-Orden $M$ and Garcia-Torres L (2002), Spatial variability of agricultural soil parameters in Southern Spain, Plant and Soil 246: 97-105. DOI:org/10.1023/A: 1021568415380

Lu RK, Shi ZY and Shi JP (2000), Nutrient balance of agro-ecosystem in six provinces in Southern China, Agricultural Science 33: 63-67.

Lui Z, Zhou W, Shen J, Lei Q and Liang G (2014), A simple assessment on spatial variability of rice yield and selected soil chemical properties of paddy fields in South China, Geoderma 235-236: 39-47. DOI:org/10.1016\%2Fj.geoderma.2014.06.027

Mabit L, Bernard C, Makhlouf M and Laverdiere MR (2008), Spatial variability of erosion and soil organic matter content estimated from ${ }^{137} \mathrm{Cs}$ measurements and geostatistics, Geoderma 145: 245-251. doi: 10.1016/j. geoderma.2008.03.013

Mallarino AP, Oyarzabal ES and Hinz PN (1999), Interpreting within field relationships between crop yields and soil plant variables using factor analysis, Precision Agriculture 1: 15-26.

McBratney AB and Pringle MJ (1999), Estimating average and proportional variograms of soil properties and their potential use in precision agriculture, Precision Agriculture 1(2): 125.

Murphy J and Riley JP (1962), A modified single solution method for the determination of phosphate in natural waters, Analytica Chimica Acta 27: 31-36. DOI:org/10.1016/S0003-2670(00)88444-5 
Parkin TB (1993), Spatial variability of microbial process in a soil-a review, Journal of Environmental Quality 22: 409-417.

Paz-Gonzalez A, Vieira SR, Ma T and Taboada Castro (2000), The effect of cultivation on the spatial variability of selected properties of an umbric horizon, Geoderma 97: 273-292.

Rehm GW, Lamb JA, Malzer GL and Davis JG (1994), Spatial variability of soil test phosphorus in a northern Corn Belt field In: Soils, Fertilizer and Agricultural Pesticides, Short Courses, 7-8 December, 1994, University of Minnesota Extension Service and Minnesota Plant Food and Chemical Association, 51-57.

Rezaei SA and Gilkes R (2005), The effects of landscape attributes and plant community on soil physical properties in rangelands, Geoderma 125(1-2): 167-176. doi: 10.1016/j.geoderma.2004.07.010

Riezebos HTh and Lorets AC (1998), Influence of land use change and tillage practice on soil organic matter in southern Brazil and eastern Paraguay, Soil \& Tillage Research 49: 271-275.

Robinson TP and Metternicht G (2006), Testing the performance of spatial interpolation techniques for mapping soil properties, America Journalof Agronomy 50: 97-108. doi:10.1016/j.compag.2005.07.003

Seatz LF and Peterson HB (1965), Acid, alkaline, saline, and sodic soils In: Chemistry of the soil, Ed. Bear FE, New York, Reinhold Pub., pp 292-319.

Tesfahunegn GB, Tamene L and Vlek PLG (2011), Catchment-scale spatial variability of soil properties and implementations on site-specific soil management in northern Ethiopia, Soil and Tillage Research 117: 124-139. DOI:org/10.1016\%2Fj.still.2011.09.005

Trangmer BB, Yost RS and Uehara G (1985), Application of Geostatistics to spatial studies of soil properties, Advance in Agronomy 38: 45-94. DOI:org/10. 1016/S0065-2113(08)60673-2

USDA (2004, Soil Survey Laboratory manual, Soil Survey Investigation Report no. 42, version 4, USDA-NRCS, Nebraska, USDA.

USDA (2016), An online document, Retrieved on April 16, 2017.Web (URL) address: $<$ http:/www.nrcs.usda.gov/ w p s / portal/n r c s/d e t a il/ $\mathrm{m} \mathrm{t} / \mathrm{hom} \mathrm{e} /$ ? cid=nrcs144p2_057697>
Vanek V, Balik J, Silha J and Cerny J (2008), Spatial variability of total soil nitrogen and sulphur content at two conventionally managed fields, Plant, Soil and Environment 54(10): 413-419.

Vetsch JA, Malzer GL, Robert PC and Huggins DR (1995), Nitrogen specific management by soil condition: managing fertilizer nitrogen in corn In: Site-specific management for agricultural systems, Eds. Robert PC et al., ASA, CSSA and SSSA, Madison, pp 465-473.

Wang Y, Zhang X and Huang C (2009), Spatial variability of soil total nitrogen and soil total phosphorus under different land uses in a small watershed on the Loess Plateau, China, Geoderma 150: 141-149. DOI:org/10.1016/j.geoderma.2009.01.021

Webster R and Oliver MA (2001), Geostatistics for environmental scientists, John Wiley \& Sons, New York, p 265.

Weindorf DC and Zhu Y (2010), Spatial Variability of Soil Properties at Capulin Volcano, New Mexico, USA: Implications for Sampling Strategy, Pedosphere 20(2): 185-197. DOI:org/10.1016/S1002-0160(10)60006-9

West CP, Mallarino AP, Wedin WF and Marx DB (1989), Spatial variability of soil chemical properties in grazed pastures, Soil Science Society of American Journal 53: 784-789.

Wu C, Wu J, Luo Y, Zhang H and Teng Y (2008), Statistical and geostatistical characterization of heavy metal concentrations in a contaminated area taking into account soil map units, Geoderma 144: 171-179. doi: 10.1016/j.geoderma.2007.11.001

Wu CF, Luo YM and Zhang LM (2010), Variability of copper availability in paddy fields in relation to selected soil properties in Southest China, Geoderma 156: 200-206.

Young FJ, Hammer RD and Larsen D (1999), Frequency distributions of soil properties on a loess-mantled Missouri watershed, Soil Science Society of America Journal 63(1): 178-185. doi:10.2136/sssaj1999. $03615995006300010025 \mathrm{x}$

Zhang HM, Xu MG, Shi XJ, Li ZZ, Huang QH and Wang XJ (2010), Rice yield, potassium uptake and apparent balance under long-term fertilization in rice-based cropping systems in Southern China, Nutrient Cycling in Agro-ecosystems 88: 341-349.

Zhou Y, Wang SJ, Lu HM, Xie L and Xiao D (2010), Forest soil heterogeneity and soil sampling protocols on limestone outctops: example from SW China, Acta Carsologica 39(1): 115-122. DOI:org/10.1155\%2 F2014\%2F473651 